\title{
Experimental and Theoretical Investigations of Spectral, Tautomerism and Acid-Base Properties of Schiff Bases Derived from Some Amino Acids
}

\author{
Y. H. Ebead, ${ }^{*}$ H. M. A. Salman, and M. A. Abdellah \\ South Valley University, Faculty of Science, Chemistry Department, 83523 Qena, Egypt. \\ *E-mail: ebeadhassan88@yahoo.com \\ Received August 18, 2009, Accepted February 2, 2010
}

\begin{abstract}
The electronic absorption spectra of five Schiff bases derived from 2-hydroxy-1-naphthaldehyde with glycine, alanine, leucine, valine and phenylalanine have been measured in various solvents. The observed bands were assigned to the proper electronic transitions and compared with the predicted transitions at the semiempirical level of theory. The calculated equilibrium constants are in agreement with the experimental results, predicting the existence of all studied compounds predominantly or completely in keto-imine tautomerism. On the other hand, a correlation between $v\left(\mathrm{~cm}^{-1}\right)(\mathrm{main}$ frequency of each compound) and the well known solvent parameters $E_{\mathrm{T}}(30), \varepsilon_{\mathrm{r}}, \pi^{*}$ has been made. Furthermore, the acid dissociation constants, $\mathrm{p} K_{\mathrm{a}}$, were determined by using three different spectrophotometric methods.
\end{abstract}

Key Words: Schiff bases, Tautomerism, DFT and PM6 calculations, $\mathrm{p} K_{\mathrm{a}}$ values and UV-vis spectra

\section{Introduction}

Schiff bases are a well-known family of compounds not only in relation to their biological activity, liquid crystals, polymer stabilizers and dyes, but also to their physicochemical properties. ${ }^{1-4}$ This may be attributed to the great flexibility and diverse structural aspects of such group of compounds. In view of this, extensive research efforts have been directed towards the preparation of amino acid Schiff bases and studying their chemical and physical properties. ${ }^{5-7}$ Currently, Schiff base metal complexes have received the attention of many research groups. ${ }^{8-11}$ This is because many of them have widespread potential applications in many fields such as catalysts for many reactions, ${ }^{12}$ treatment of cancer, ${ }^{13}$ antibactericide agents, ${ }^{14}$ antivirus agents, ${ }^{15}$ and other biological properties. ${ }^{16}$ Nowadays, the demand for such group of compounds has increased as a result of several new optical and organic conducting materials that can be produced by these compounds. ${ }^{17,18}$ Schiff bases can also serve as photochromic compounds. ${ }^{19}$

Considering their significant biological activity, pharmacological and physicochemical properties, Schiff bases are extremely important especially those which participate in tautomeric equilibiria between imine and keto forms. On the other hand, amino acids and their derivatives are used for a variety of applications in industry and in the synthesis of drugs and cosmetics. ${ }^{20}$ To the best of our knowledge the electronic absorption spectra of many Schiff bases which are structurally related to the present compounds have been thoroughly investigated. ${ }^{9,21-23}$ However, we did not come across with any detailed of experimental and calculated of electronic spectra or the tautomerism process of compounds 1-5 in gaseous phase or in solution. Thus, the above findings have enamored us to take an endeavor to synthesis compounds 1-5 and to study their spectral features as well as to investigate their ability to co-exist in various tautomeric forms or solely in imine or keto forms theoretically and experimentally. Such phenomenon plays an important role in determining the chemistry, biological and therapeutic activity of several compounds. ${ }^{24}$ Lastly, we expected to find how far experimental findings are reflected in theoretical predictions and what kind of information can be extracted from spectroscopic investigations. However, the usefulness of electronic spectroscopy in studies of tautomeric phenomena of this group of compounds and other biologically potential compounds has been demonstrated earlier. ${ }^{25-28}$ On the other hand, the knowledge of $\mathrm{p} K_{\mathrm{a}}$ values provides a basis for understanding of the chemical reactions between the compound of interest and its pharmacological target. Additionally, they play a major role in acid-base titrations, complex formation and many other analytical procedures. Also, the $\mathrm{p} K_{\mathrm{a}}$ value(s) of a compound influence many characteristics such as its reactivity and spectral properties (color). The present piece of work involves synthesis, spectroscopic characterization, semiempirical, ab intio computational calculations and acid-base properties of a set of amino acid Shiff bases (Scheme 1).

\section{Experimental}

Synthesis of the subjected compounds (Scheme 1). Schiff bases (1-5) under investigation were prepared according to the procedure previously described in the literature. ${ }^{21}$ Thus, a solution of 2-hydroxy-1-naphthaldehyde ( $5 \mathrm{mmol}, 0.86 \mathrm{~g}$ ) dissolved in hot ethanol $(20 \mathrm{~mL})$ ) was added gradually with stirring to an equimolar amount of amino acid ( $5 \mathrm{mmol}$ ) [glycine, alanine, leucine, valine and phenylalanine] dissolved in a 1:1 waterethanol mixture $(20 \mathrm{~mL})$. The mixture was stirred for 8 hours on a water bath at $70{ }^{\circ} \mathrm{C}$. The obtained precipitate was filtered off and washed with cold ethanol. The solid products were recrystallized from hot methanol to give yellow crystals, dried in vacuo over silica gel. The purity of the prepared compounds was checked by elemental analysis, IR and ${ }^{1} \mathrm{H}$ NMR spectra (Table 1).

Measurements. The chemical composition of the products was proved by elemental analysis using Carlo-Erba (model EAGER 200) instrument. Melting points were determined by 
<smiles>[R]C(N=Cc1c(O)ccc2ccccc12)C(=O)O</smiles><smiles>[R]C(N/C=C1\C(=O)C=Cc2ccccc21)C(=O)O</smiles>

Scheme 1. Canonic structures of the keto and imine forms of compounds 1-5 with the numbering of atoms indicated: $\mathrm{R}=\mathrm{H}(\mathbf{1}), \mathrm{CH}_{3}$ (2), $\mathrm{CH}_{2} \mathrm{CH}\left(\mathrm{CH}_{3}\right)_{2}$ (3), $\mathrm{CH}\left(\mathrm{CH}_{3}\right)_{2}$ (4), $\mathrm{CH}_{2} \mathrm{C}_{6} \mathrm{H}_{5}$ (5)<smiles>[R]C(N=Cc1c(O)ccc2ccccc12)C(=O)O</smiles>

Scheme 2. Acid-base equilibrium

Electro-thermal melting point apparatus. ${ }^{1} \mathrm{H}$ NMR spectra for saturated solutions of compounds (1-5) in dimethylsulfoxide- $d_{6}$ $\left(\mathrm{DMSO}-d_{6}\right)$ were taken on a Varian Mercury VX-300 MHz spectrometer.

The electronic absorption spectra were recorded on a Shimadzu 2401 PC spectrophotometer using 1-cm matched quartz cell. All the solvents used in this investigation were of spectral grade. Infrared spectra of the solids were performed on a FT-IR Bruker Vector 22 using the $\mathrm{KBr}$ technique. The $\mathrm{pH}$ measurements were carried out using an Orion 501 digital ionalyzer accurate to $\pm 0.01 \mathrm{pH}$ unit. The $\mathrm{pH}$ control was achieved by using modified universal buffer solutions. ${ }^{29}$ To account for differences in acidity, basicity, dielectric constant, and ion activities in partially aqueous media relative to pure aqueous solutions, where the $\mathrm{pH}$ meter is standardized using aqueous buffers at $25{ }^{\circ} \mathrm{C}$. The $\mathrm{pH}$ values in the former media were corrected by using procedure described by Douheret (eq 1), where the meter reading $\mathrm{pH}_{(\mathrm{R})}$ obtained in water ethanol mixture differs by amount $\delta$ from the corrected reading $\mathrm{pH}^{*}{ }^{30}$

$$
\mathrm{pH}^{*}=\mathrm{pH}_{(\mathrm{R})}-\delta
$$

Values of $\delta$ for various aqueous + organic ethanol mixtures were determined as recommended by Douheret at the same ionic strength. ${ }^{30,31}$ All the measurements were carried out at room temperature $\left(25^{\circ} \mathrm{C}\right)$.

Quantum chemical calculations. The fully geometry optimization of the isolated molecules (Scheme 1) were carried out at the level of semiempirical PM6 method, ${ }^{32}$ as well as density functional (DFT) ${ }^{33}$ using gradient technique ${ }^{34,35}$ and $6-31 \mathrm{G}^{* * 36,37}$ basis set. The DFT calculations were carried out with the B3LYP functional, in which Becke's nonlocal exchange ${ }^{38,39}$ and the LeeYang-Parr correlation functionals ${ }^{40}$ were applied. After the completion of the optimization, the Hessian (second derivatives of the energy as a function of the nuclear coordinates) was calculated and checked for positive definiteness to assess whether the structures were true minima. ${ }^{33,41}$ The harmonic vibrational frequencies were then derived from the numerical values of these second derivatives and used to obtain the Gibbs' free energy contributions at $298.15 \mathrm{~K}$ and standard pressure. Ab initio calculations were performed using the GAUSSIAN 03 for Windows program package. ${ }^{42}$ Solvent effects on tautomers were also investigated using PM6 (COSMO) model $^{32}$ as implemented in MOPAC 2009. ${ }^{43}$ The wavelengths of the electronic transitions in absorption spectra were calculated at AM1 with a $10 \times 10 \mathrm{CI}$ singly excited matrix. ${ }^{44}$ All calculations were done on a Pentium IV PC computer.

\section{Results and Discussion}

Structural identification. FT-IR and ${ }^{1} \mathrm{H}$ NMR spectral data listed in Table 1 confirm the structures of the subjected compounds. The FT-IR spectra of the Schiff bases 1-5 showed a strong absorption bands at $1580-1648 \mathrm{~cm}^{-1}$ as an overlap which were attributable to stretching vibration of the $v(\mathrm{C}=\mathrm{O})$ and $v$ $(\mathrm{C}=\mathrm{N})$, confirming the existence both of keto and imine tautomers in the solid state. ${ }^{8,21}$ Further, a medium band at 3350 $3450 \mathrm{~cm}^{-1}$ due to the vibration of NH bond supporting the presence of keto and imine forms. Since, these amino acid Schiff bases do not exist as their salts, ionized $\mathrm{COO}^{-}$asymmetric and symmetric stretching bands are not observed. Only the non-ionized COO stretching frequency at $1717-1736 \mathrm{~cm}^{-1}$ is observed. ${ }^{45}$ The bands appeared in the range $3150-3060 \mathrm{~cm}^{-1}$ and $1558-1551 \mathrm{~cm}^{-1}$ due to $v(\mathrm{OH})$ and $v(\mathrm{C}=\mathrm{C})$, respectively, provide a further evidence for the presence of the tautomeric forms of the prepared compounds (1-5).

The ${ }^{1} \mathrm{H}$ NMR spectra of the investigated compounds showed three sets of signals. A singlet at 13.80 - 14.50 ppm corresponds to $\mathrm{H}_{16}$ proton of the carboxylic group. Also a sharp singlet signal near $8.77-9.10 \mathrm{ppm}$ was observed and attributed to the $\mathrm{H}_{12}$ for $\mathrm{CH}=\mathrm{N}$ - group (Scheme 1). The multipletes observed in the region $6.70-8.08 \mathrm{ppm}$ are ascribed to the aromatic hydrogens. However, aliphatic protons appear in the expected region, which confirms the suggested chemical structure of the investigated compounds (Table 1). The pattern of ${ }^{1} \mathrm{H}$ NMR spectra of all Schiff bases investigated here show only one group of signals since the equilibrium between the two tautomers is very fast.

Structure and physicochemical properties. All the compounds investigated can coexist in the keto and imine tautomeric forms (Scheme 1). Figure 1 shows DFT optimized structures of all the possible tautomers and Table 2 provides selected structural information. As results from geometry optimizations imine tautomers possess rigid planar polycyclic fragment as well as keto form in 5, however, keto forms are essentially non-planar, a situation reflected by the respective dihedral angles listed in Table 2. This finding is in agreement with the results obtained from X-ray structural determinations of $N$-(2-hydroxy-1-naph- 
1

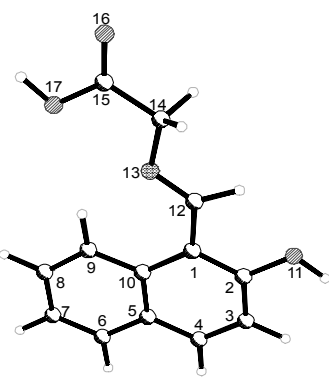<smiles>C=C(OC)C(CC(C)C1C(C(C)C)C(C)C(C)C2C(C)C(C)C(C)C(C)C21)=C(C)C</smiles>

3

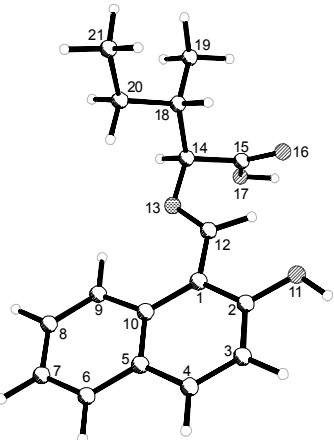

4

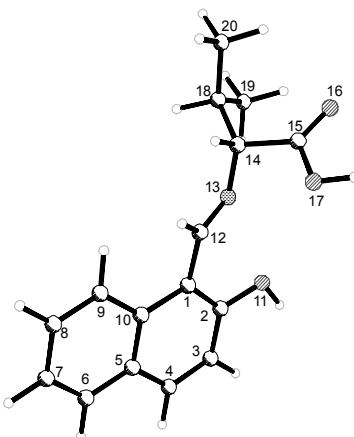

5

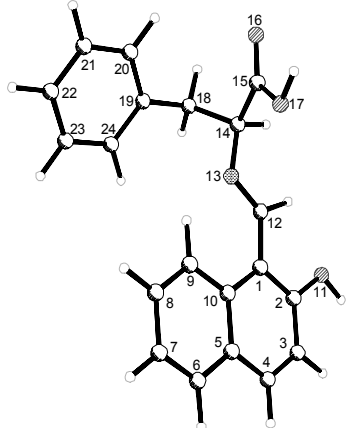

Imine form<smiles>COC(=O)C(C)(C)C(C)C(C)C1C(C)C(C)=C(C)C2C(O)C(C)C(C)C(C)C(C)C21</smiles>

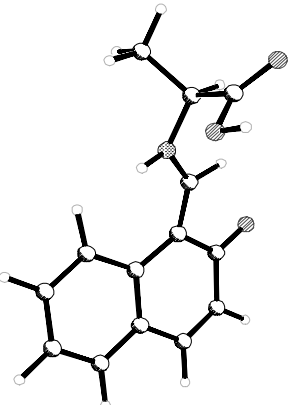

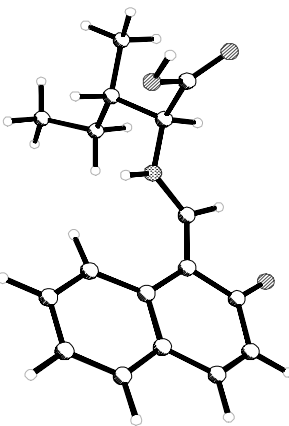<smiles>COC(=O)C(C)(C(C)C(C)C1C(O)C(C)C(C)C2C(C)C(C)C(C)C(C)C21)C(C)C(C)(C)C(C)(C)C</smiles>

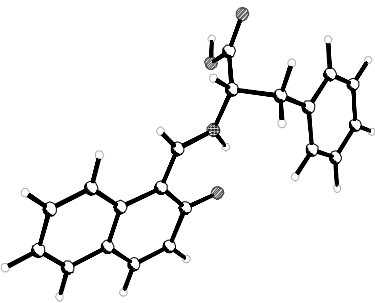

Keto form

Figure 1. The DFT- optimized structures of the tautomers of Schiff bases 1.

thylidene)threonine, which exhibited a structural features of the imine form. ${ }^{46}$ Furthermore, the crystallographic measurements revealed that the slight distorted planarity of the naphthylidene moiety as reflected in the values of respective dihedral angles reported in reference. ${ }^{46}$ In the course of our results, DFT and PM6 theoretical methods provide structural data which well correlate with experimental $\mathrm{X}$-ray data for the imine tautomers. This is seen by comparing values of the $\mathrm{C}_{10} \mathrm{C}_{1} \mathrm{C}_{2} \mathrm{O}_{11}$ dihedral angle between the experimental results and the predicted ones (Table 2). Another interesting feature is that DFT and semiempirical methods predict that $\mathrm{C}_{12}-\mathrm{N}_{13}$ bond length well corresponding to typical double bond of the imine forms $(\sim 1.28 \AA)$. However, the slight elongation of the same bond $(1.31 \AA)$ has been experimentally observed and the discrepancy between the measured value and the expected one was explained by the $\pi$-electron delocalization.

Charge at $\mathrm{N}_{13}$ extracted from PM6 calculations and electrostatic-potential derived charge based on the CHELPG methods ${ }^{47}$ was calculated to provide an indication of the influence of the substituent at position on one characteristic structural property. The theoretical methods applied predict that imine tautomers exhibit unique distribution of atomic partial charge around $\mathrm{N}_{13}$ and calculated a large partial negative charge for the imine tautomers values compared with that of keto forms (Table 2). This information is an important feature worth of taking into account in investigations of specific interactions of the compounds with other molecules

Distinct change in dipole moment values is noted on passing from gaseous to liquid phase. From these considerations it emerges that the theoretical data predicted for the tautomerization particularly the equilibrium constants may be a good reflection of the situation occurring in liquid phases.

A first glance to Table 2 shows that the equilibrium constants of tautomerization for compounds 1-5 are so high that one gets the impression that these compounds are virtually completely exist in keto form in the gaseous phase. Indeed, x-ray data for compounds related to the investigated compounds confirm this. ${ }^{48,49}$ On passing from gaseous to liquid phase, however, in contrast, our calculations suggest that keto and imine tautomers can coexist and tautomeric equilibrium is strongly affected by the properties of the medium since tautomers exhibit various polarities and distribution of charge around the molecules (Table 2). It is noteworthy, here to emphasize that tautomeric equilibria in various Schiff bases derived from amino acids have been monitored by ${ }^{1} \mathrm{H}$ NMR, UV-vis and IR spectroscopy and our results correspond well with those reported elsewhere by others. $8,21,46,50$

Electronic absorption spectra in ethanol. The values of $\lambda_{\max }$ and the extinction coefficients $(\log \varepsilon)$ of the characteristic absorption bands of the examined compounds (1-5) in seven organic solvents are listed in Table 3 . Figure 2 represents the absorption spectra of the Schiff bases studied in ethanol. As mentioned herein and elsewhere, amino acid Schiff bases can exist in two tautomeric forms. Hence, one can expect tautomeric equilibiria in which all forms of comparable energies occur in the liquid phase. To facilitate interpretation of experimental spectra, we compared them with the predicted wavelengths of electronic transitions at AM1/CI level. Based on the data cited 
Table 1. Microchemical analysis data, melting points, IR and ${ }^{1} \mathrm{H}$ NMR spectra of the synthesized Schiff bases

\begin{tabular}{|c|c|c|c|c|c|c|c|c|c|c|c|}
\hline \multirow{2}{*}{ Comp. } & \multirow{2}{*}{ Formula } & \multirow{2}{*}{$\begin{array}{l}\left.\mathrm{mp}^{\circ} \mathrm{C}\right) \\
\left({ }^{\circ}\right)\end{array}$} & \multicolumn{3}{|c|}{$\begin{array}{l}\% \text { Calculated } \\
\text { (Found) }\end{array}$} & \multicolumn{5}{|c|}{$\operatorname{IR} v\left(\mathrm{~cm}^{-1}\right)$} & \multirow{2}{*}{${ }^{1} \mathrm{H}$ NMR (ppm) } \\
\hline & & & $\mathrm{C}$ & $\mathrm{H}$ & $\mathrm{N}$ & $v(\mathrm{OH}) v(\mathrm{NH})$ & $v_{\text {asy }}(\mathrm{COO})$ & $v_{\mathrm{sy}}(\mathrm{COO})$ & $\begin{array}{c}v(\mathrm{C}=\mathrm{O}) \\
(v(\mathrm{C}=\mathrm{N}))\end{array}$ & $v(\mathrm{C}=\mathrm{C})$ & \\
\hline 1 & $\mathrm{C}_{13} \mathrm{H}_{11} \mathrm{NO}_{3}$ & 205 & $\begin{array}{c}67.78 \\
(68.11)\end{array}$ & $\begin{array}{c}4.30 \\
(4.84)\end{array}$ & $\begin{array}{c}6.18 \\
(6.11)\end{array}$ & $3132_{\mathrm{m}} 3360_{\mathrm{m}}$ & $1717_{\mathrm{s}}$ & $1300_{\mathrm{s}}$ & $\begin{array}{l}1648_{\mathrm{vs}} \\
\left(1619_{\mathrm{s}}\right)\end{array}$ & $1509_{\mathrm{m}}$ & $\begin{array}{l}13.80(\mathrm{~s}, 1 \mathrm{H},-\mathrm{COOH}), 9.05(\mathrm{~s}, 1 \mathrm{H}, \\
-\mathrm{CH}), 6.70-8.02(\mathrm{~m}, 6 \mathrm{H}-\mathrm{Ar}), 4.50(\mathrm{~s}, \\
\left.2 \mathrm{H},-\mathrm{CH}_{2}\right) .\end{array}$ \\
\hline 2 & $\mathrm{C}_{14} \mathrm{H}_{13} \mathrm{NO}_{3}$ & 165 & $\begin{array}{c}68.98 \\
(69.12)\end{array}$ & $\begin{array}{c}5.20 \\
(5.39)\end{array}$ & $\begin{array}{c}5.62 \\
(5.76)\end{array}$ & $2998_{\mathrm{m}} 3450_{\mathrm{m}}$ & $1722_{\mathrm{s}}$ & $1309_{\mathrm{s}}$ & $\begin{array}{c}1641_{\mathrm{s}} \\
\left(1629_{\mathrm{s}}\right)\end{array}$ & $1516 \mathrm{~m}$ & $\begin{array}{l}13.91(\mathrm{~s}, 1 \mathrm{H},-\mathrm{COOH}), 9.06(\mathrm{~s}, 1 \mathrm{H}, \\
-\mathrm{CH}), 6.75-8.05(\mathrm{~m}, 6 \mathrm{H}-\mathrm{Ar}), 4.60(\mathrm{q}, \\
1 \mathrm{H},-\mathrm{CH}), 1.70\left(\mathrm{~d}, 3 \mathrm{H},-\mathrm{CH}_{3}\right) .\end{array}$ \\
\hline 3 & $\mathrm{C}_{17} \mathrm{H}_{19} \mathrm{NO}_{3}$ & 185 & $\begin{array}{c}71.20 \\
(71.50)\end{array}$ & $\begin{array}{c}6.80 \\
(6.71)\end{array}$ & $\begin{array}{c}4.90 \\
(4.91)\end{array}$ & $3045_{\mathrm{s}} 3350_{\mathrm{m}}$ & $1736_{s}$ & $1285_{\mathrm{m}}$ & $1641_{\mathrm{s}}$ & $1516_{\mathrm{m}}$ & $\begin{array}{l}14.35(\mathrm{~s}, 1 \mathrm{H},-\mathrm{COOH}), 9.10(\mathrm{~s}, 1 \mathrm{H}, \\
-\mathrm{CH}), 6.73-8.07(\mathrm{~m}, 6 \mathrm{H}-\mathrm{Ar}), 4.30(\mathrm{~d}, \\
1 \mathrm{H},-\mathrm{CH}), 2.00(\mathrm{~m}, 1 \mathrm{H},-\mathrm{CH}), 1.20-1.40 \\
(\mathrm{~m}, 2 \mathrm{H},-\mathrm{CH} 2), 0.95-0.85\left(6 \mathrm{H}, 2 \mathrm{CH}_{3}\right) .\end{array}$ \\
\hline 4 & $\mathrm{C}_{16} \mathrm{H}_{17} \mathrm{NO}_{3}$ & 187 & $\begin{array}{c}70.20 \\
(70.80)\end{array}$ & $\begin{array}{c}6.02 \\
(6.32)\end{array}$ & $\begin{array}{c}5.10 \\
(5.16)\end{array}$ & $3062_{\mathrm{s}} 3450_{\mathrm{m}}$ & $1723_{s}$ & $11285_{\mathrm{m}}$ & $\begin{array}{c}1640_{\mathrm{s}} \\
\left(1580_{\mathrm{m}}\right)\end{array}$ & $1516_{\mathrm{m}}$ & $\begin{array}{l}14.50(\mathrm{~s}, 1 \mathrm{H},-\mathrm{COOH}), 9.14(\mathrm{~s}, 1 \mathrm{H}, \\
-\mathrm{CH}), 6.77-8.08(\mathrm{~m}, 6 \mathrm{H}-\mathrm{Ar}), 4.33(\mathrm{~d}, \\
1 \mathrm{H},-\mathrm{CH}), 2.31(\mathrm{~m}, 1 \mathrm{H},-\mathrm{CH}), 0.95(\mathrm{~d}, \\
\left.6 \mathrm{H}, 2 \mathrm{CH}_{3}\right) .\end{array}$ \\
\hline 5 & $\mathrm{C}_{20} \mathrm{H}_{17} \mathrm{NO}_{3}$ & 170 & $\begin{array}{c}74.75 \\
(75.22)\end{array}$ & $\begin{array}{c}5.38 \\
(5.37)\end{array}$ & $\begin{array}{c}4.22 \\
(4.40)\end{array}$ & $3090_{\mathrm{s}} 3400_{\mathrm{m}}$ & $1731_{s}$ & $1290_{\mathrm{m}}$ & $\begin{array}{l}1634_{\mathrm{s}} \\
\left(1616_{\mathrm{m}}\right)\end{array}$ & $1502_{\mathrm{s}}$ & $\begin{array}{l}14.00(\mathrm{~s}, 1 \mathrm{H},-\mathrm{COOH}), 8.77(\mathrm{~s}, 1 \mathrm{H}, \\
-\mathrm{CH}), 6.70-7.83(\mathrm{~m}, 11 \mathrm{H}-\mathrm{Ar} .), 4.60(\mathrm{t}, \\
1 \mathrm{H},-\mathrm{CH}), 2.80\left(\mathrm{~d}, 2 \mathrm{H},-\mathrm{CH}_{2}\right) .\end{array}$ \\
\hline
\end{tabular}

vs- very strong, s- strong, m- medium and w- week

in the former table, absorption spectra of compounds 1-5 occur in two to three regions in most of the solvents used. Long wavelength, complex and broad bands are seen in the visible region. Short wavelength band - appearing near $300 \mathrm{~nm}$ - is best attributed to ring localizes $\pi-\pi^{*}$ transition within the fused aromatic rings. Actually, this assignment completely opposes considerable publications which ascribed it to $n-\pi^{*}$ transition within imine form. ${ }^{9,46}$ Our assignment is supported by the following facts: The position of the band is more or less influenced by the nature of the amino acid and/or the solvents. The shape and position of this band is independent on the $\mathrm{pH}$ values (Figure 5). On the other hand, the assignments of the visible bands together with the pattern of visible spectra in universal buffer solutions substantiate the above description as will be subsequently discussed. Investigators who assigned this band to $n-\pi^{*}$ transition within imine form based their decision on the spectra of amino acid Schiff bases derived from 3-hydroxypyridine-4-aldehyde and 3-hydroxypyridine-2-aldehyde. ${ }^{22,23}$ In fact, the shape of the electronic absorption spectra of the amino acid Schiff bases derived from 2-hydroxy-1-naphthaldehyde dose not resemble the former one.

The characteristic visible electronic bands appearing in the range 400 - $422 \mathrm{~nm}$ contain elements characteristic of both keto and imine forms (Scheme 1, Figure 2). Such tautomerization ability is demonstrated by the composite nature of the main visible band. Therefore, it is possible to assign the shorter wavelength band to $\pi-\pi^{*}$ transition involving the $\pi$ - electronic system throughout the whole molecule with a considerable charge transfer (CT) character within the imine form. Meanwhile the longer band can be ascribed to a similar transition within the keto tautomer. This follows the conclusion arising from the electronic absorption transitions predicted for the tautomers investigated here (Table 4). The CT nature of this band is achieved from its broadness $^{51}$ and the nature of the solvent. In addition, the CT character of this band is further substantiated by obtaining a good straight line passing through the origin point on plotting the absorbance of this band versus the molar concentration of the Schiff bases (Figure 3).

Generally, the long wavelength bands in compounds 1-5 appear in the same spectral region, which means that the energy gaps between the ground and excited levels are similar in all compounds. However, keto tautomers were predicted to absorb light at longer wavelength compared to imine ones. Consequently, positive solvatochromism of the visible band should be noted on transferring from the latter tautomer to the former one. The results given in Table 4, the calculations - based on AM1 geometries - predicted a very small intensity ( $f$ ) for the longest wavelength transition bands in the case of the imine tautomers relative to $\pi-\pi^{*}$ transition within the keto forms. Generally, the above findings are in harmony with the experimental UV-vis spectra to some extent, discrepancies between experimental and calculated values - in wavelengths - is partly due to the fact that computations were carried out for isolated molecules, while in liquid phase solvation effects should be taken into account (Table 3).

Further supporting for the above assignment is given by spectral behavior in buffer solutions of varying $\mathrm{pH}$ values. The visible spectra of compounds 1-5 in acidic medium displayed only one band at $\approx 371 \mathrm{~nm}$ associated with shoulder at longer wavelength. This band can be ascribed without any doubt to the absorption by imine form. This premise is reasonable since $\mathrm{N}_{13}$ atom which is responsible for the accommodation of the migrated $\mathrm{OH}$ proton is blocked by the hydrogen of the medium. On increasing the $\mathrm{pH}$ of the medium the intensity of the band decays gradually with the increasing of the $\mathrm{pH}$, while the shoulder (due to absorption by keto form) gets a higher absorbance. Such ioni- 
Table 2. Structural and physicochemical features of tautomers of compounds 1-5

\begin{tabular}{|c|c|c|c|c|c|c|c|c|}
\hline \multirow{2}{*}{ Computational level } & \multicolumn{2}{|c|}{ Dihedral angle $^{a}$} & \multicolumn{2}{|c|}{ Dipole moment (D) } & \multicolumn{2}{|c|}{ Charge at $\mathrm{N}_{13}$} & \multirow{2}{*}{$\Delta E$} & \multirow{2}{*}{$\ln _{298} K^{0}$} \\
\hline & imine & keto & imine & keto & imine & keto & & \\
\hline \multicolumn{9}{|c|}{1} \\
\hline DFT & $-180(-180.2)^{b}$ & -172.80 & 4.52 & 4.64 & -0.40 & -0.32 & -0.10 & 5.67 \\
\hline PM6 & 179.15 & 166.81 & 4.89 & 3.87 & -0.34 & -0.30 & -0.13 & 1.65 \\
\hline PM6 (COSMO-DMF) & 179.80 & 174.20 & 5.71 & 8.52 & -0.36 & -0.25 & -0.27 & 2.43 \\
\hline PM6 (COSMO- $\left.\mathrm{C}_{2} \mathrm{H}_{5} \mathrm{OH}\right)$ & 179.70 & 174.00 & 6.34 & 8.37 & -0.36 & -0.26 & -0.28 & 2.46 \\
\hline PM6 (COSMO-Acetone) & 179.70 & 174.18 & 6.32 & 8.30 & -0.36 & -0.26 & -0.28 & 2.46 \\
\hline PM6 (COSMO-CCl $)$ & 179.15 & 174.24 & 5.38 & 6.03 & -0.33 & -0.32 & -0.21 & 2.13 \\
\hline \multicolumn{9}{|c|}{2} \\
\hline DFT & -179.87 & 172.46 & 2.82 & 4.54 & -0.43 & -0.38 & -0.11 & 4.51 \\
\hline PM6 & -178.15 & -157.76 & 5.09 & 5.93 & -0.34 & -0.31 & -0.03 & 0.65 \\
\hline PM6 (COSMO-DMF) & 179.79 & -170.41 & 4.02 & 9.51 & 0.40 & -0.26 & -0.14 & 1.81 \\
\hline PM6 (COSMO- $\left.\mathrm{C}_{2} \mathrm{H}_{5} \mathrm{OH}\right)$ & 179.70 & -172.69 & 7.59 & 10.0 & -0.41 & -0.23 & -0.10 & 1.52 \\
\hline PM6 (COSMO-Acetone) & 179.77 & -170.87 & 7.56 & 9.25 & -0.41 & -0.27 & -0.06 & 1.15 \\
\hline PM6 (COSMO-CCl $)$ & 178.75 & -159.86 & 6.94 & 6.24 & -0.36 & -0.31 & -0.01 & 0.09 \\
\hline \multicolumn{9}{|c|}{3} \\
\hline DFT & -180.00 & 172.36 & 2.85 & 5.68 & -0.42 & -0.29 & -0.11 & 3.05 \\
\hline PM6 & -179.41 & -157.26 & 4.65 & 2.55 & -0.34 & -0.31 & 0.01 & -3.52 \\
\hline PM6 (COSMO-DMF) & -179.78 & 167.50 & 3.57 & 9.30 & -0.41 & -0.24 & -0.13 & 1.76 \\
\hline PM6 (COSMO- $\left.\mathrm{C}_{2} \mathrm{H}_{5} \mathrm{OH}\right)$ & -179.80 & 167.07 & 3.52 & 9.13 & -0.40 & -0.25 & -0.12 & 1.74 \\
\hline PM6 (COSMO-Acetone) & -179.86 & 167.29 & 3.52 & 9.04 & -0.40 & -0.25 & -0.11 & 1.71 \\
\hline PM6 (COSMO-CCl 4 ) & -179.55 & 161.65 & 2.94 & 6.06 & -0.35 & -0.32 & -0.01 & 0.08 \\
\hline \multicolumn{9}{|c|}{4} \\
\hline DFT & 179.99 & 173.25 & 2.91 & 5.61 & -0.43 & -0.39 & -0.27 & 8.27 \\
\hline PM6 & -179.34 & 169.19 & 4.38 & 2.52 & -0.32 & -0.30 & -0.02 & 0.51 \\
\hline PM6 (COSMO-DMF) & -180.00 & 168.32 & 3.53 & 9.19 & -0.38 & -0.23 & -0.15 & 1.89 \\
\hline PM6 (COSMO- $\left.\mathrm{C}_{2} \mathrm{H}_{5} \mathrm{OH}\right)$ & 179.99 & 166.54 & 3.49 & 8.99 & -0.38 & -0.24 & -0.14 & 1.84 \\
\hline PM6 (COSMO-Acetone) & 179.99 & 166.27 & 3.48 & 8.90 & -0.38 & -0.24 & -0.14 & 1.82 \\
\hline PM6 (COSMO-CCl $\left.{ }_{4}\right)$ & -178.24 & 171.52 & 3.38 & 5.61 & -0.35 & -0.30 & -0.04 & 0.88 \\
\hline \multicolumn{9}{|c|}{5} \\
\hline DFT & 179.87 & 179.50 & 4.17 & 2.05 & -0.40 & -0.35 & -0.45 & 2.78 \\
\hline PM6 & 179.36 & -179.10 & 2.98 & 3.64 & -0.36 & -0.32 & -0.40 & 2.79 \\
\hline PM6 (COSMO-DMF) & -179.29 & 178.95 & 6.75 & 4.90 & -0.39 & -0.29 & -0.49 & 3.00 \\
\hline PM6 (COSMO- $\left.\mathrm{C}_{2} \mathrm{H}_{5} \mathrm{OH}\right)$ & -179.27 & -178.74 & 6.61 & 4.80 & -0.38 & -0.29 & -0.50 & 3.01 \\
\hline PM6 (COSMO-Acetone) & -179.28 & 168.83 & 6.58 & 4.71 & -0.38 & -0.29 & -0.49 & 3.00 \\
\hline PM6 (COSMO-CCl 4$)$ & -179.26 & -178.71 & 5.34 & 3.02 & -0.36 & -0.32 & -0.53 & 3.07 \\
\hline
\end{tabular}

${ }^{a}$ Between $\mathrm{C}_{10} \mathrm{C}_{1} \mathrm{C}_{2} \mathrm{O}_{11},{ }^{b}$ from ref.[46], $\Delta E$, in ev, is the energy difference between the keto and imine tautomeric forms for the same molecule, $\ln _{298} K=$ $-\Delta G / \mathrm{RT}$.

zation process increases the electron density on the naphthol ring and consequently increases the amount of keto form. Accordingly, the shoulder observed in the spectra of compounds 1-5 in solutions of low pH's may be due to some quantities of the keto form, despite that the predominance of the imine forms.

Long wavelength bands in the absorption spectra of the compounds investigated are influenced somewhat by features of the medium (Table 5). The effort was thus made to find correlations between the position of maxima of long wavelength bands $\left(v_{\max }\right)$ and values of selected parameters characterizing the used solvents $\left(\pi^{*}\right)$, where $\pi^{*}$ is a measure of solvent dipolarity/ polarizability, ${ }^{52}$ dielectric constant $\left(\varepsilon_{\mathrm{r}}\right)$, Dimorth and Reichard solvent polarity parameter, $E_{\mathrm{T}}(30){ }^{53-55}$ Plots of $v_{\max }$ versus the above mentioned parameters showed no regular relations between the two variables. This denotes that the dielectric constants as well as the other parameters are not main factors affecting the CT band position (Figure 4). Accordingly, specific solute-solvent interactions leading to solvation of the solute molecules in the ground and excited states are to be considered.

Acid dissociation constants. The acidity constants $\left(\mathrm{p} K_{\mathrm{a}}\right)$ of the 
Table 3. Electronic absorption spectral data of the Schiff bases 1-5 in pure organic solvents at $25{ }^{\circ} \mathrm{C}$

\begin{tabular}{|c|c|c|c|c|c|c|c|c|c|c|c|c|c|c|}
\hline \multirow{2}{*}{ Compound } & \multicolumn{2}{|c|}{$\mathrm{C}_{2} \mathrm{H}_{5} \mathrm{OH}$} & \multicolumn{2}{|c|}{$\mathrm{CH}_{3} \mathrm{OH}$} & \multicolumn{2}{|c|}{ DMF } & \multicolumn{2}{|c|}{ DMSO } & \multicolumn{2}{|c|}{ Acetone } & \multicolumn{2}{|c|}{$\mathrm{CHCl}_{3}$} & \multicolumn{2}{|c|}{$\mathrm{CCl}_{4}$} \\
\hline & $\lambda_{\max }$ & $\log \varepsilon$ & $\lambda_{\max }$ & $\log \varepsilon$ & $\lambda_{\max }$ & $\log \varepsilon$ & $\lambda_{\max }$ & $\log \varepsilon$ & $\lambda_{\max }$ & $\log \varepsilon$ & $\lambda_{\max }$ & $\log \varepsilon$ & $\lambda_{\max }$ & $\log \varepsilon$ \\
\hline \multirow{3}{*}{1} & 419 & 2.893 & 418 & 2.902 & 421 & 2.785 & 421 & 2.763 & 419 & 2.746 & 421 & 2.670 & 418 & 2.803 \\
\hline & 400 & 2.891 & 400 & 2.898 & 401 & 2.784 & 402 & 2.769 & 400 & 2.752 & 402 & 2.681 & 400 & 2.823 \\
\hline & 307 & 2.937 & 308 & 2.926 & 307 & 2.934 & 307 & 2.942 & & & 310 & 2.871 & 307 & 2.865 \\
\hline \multirow{4}{*}{2} & 419 & 2.730 & 418 & 2.784 & 422 & 2.703 & 421 & 2.701 & 419 & 2.628 & 421 & 2.623 & 418 & 2.646 \\
\hline & 401 & 2.734 & 401 & 2.792 & 402 & 2.712 & 402 & 2.716 & 400 & 2.638 & 402 & 2.636 & 401 & 2.683 \\
\hline & 369 & 2.732 & 375 & 2.744 & 362 & 2.744 & 361 & 2.765 & 358 & 2.752 & 361 & 2.732 & 371 & 2.679 \\
\hline & 311 & 2.967 & 311 & 2.975 & 310 & 2.983 & 309 & 2.995 & & & 313 & 2.944 & 312 & 2.907 \\
\hline \multirow{3}{*}{3} & 420 & 3.011 & 419 & 3.030 & 423 & 2.983 & 424 & 2.996 & 420 & 2.891 & 421 & 2.875 & 420 & 2.893 \\
\hline & 401 & 2.989 & 401 & 3.010 & 403 & 2.968 & 404 & 2.979 & 401 & 2.882 & 404 & 2.871 & 401 & 2.895 \\
\hline & 308 & 2.995 & & & 307 & 3.038 & 308 & 3.022 & & & 309 & 3.023 & 307 & 3.051 \\
\hline \multirow{3}{*}{4} & 420 & 3.016 & 418 & 3.060 & 422 & 2.974 & 422 & 2.985 & 420 & 2.889 & 421 & 2.922 & 419 & 2.955 \\
\hline & 401 & 3.003 & 400 & 3.043 & 402 & 2.965 & 402 & 2.978 & 401 & 2.888 & 403 & 2.918 & 401 & 2.952 \\
\hline & 306 & 3.008 & 307 & 3.014 & 307 & 3.039 & 307 & 3.061 & & & 309 & 2.989 & 307 & 2.948 \\
\hline \multirow{4}{*}{5} & 422 & 2.881 & 420 & 2.889 & 425 & 2.920 & 426 & 2.952 & 422 & 2.714 & 423 & 2.734 & 421 & 2.681 \\
\hline & 403 & 2.866 & 402 & 2.869 & 404 & 2.899 & 405 & 2.922 & 402 & 2.710 & 404 & 2.724 & 402 & 2.701 \\
\hline & 309 & 2.937 & 380 & 2.918 & 373 & 2.630 & 309 & 2.979 & 363 & 2.621 & 366 & 2.636 & 376 & 2.85 \\
\hline & 380 & 2.690 & 309 & 2.680 & 309 & 2.990 & & & & & 311 & 2.914 & 311 & 2.847 \\
\hline
\end{tabular}

$\lambda_{\max }$-position of band maxima in absorption spectra (in $\mathrm{nm}$ ), $\varepsilon$ - absorption coefficients (in $\mathrm{M}^{-1} \mathrm{~cm}^{-1}$ ), sh - shoulder

Table 4. Wavelengths (nm) and oscillator strengths (in parentheses) of electronic absorption transitions predicted at AM1/CI level of theory

\begin{tabular}{|c|c|c|c|c|c|}
\hline Compound & 1 & 2 & 3 & 4 & 5 \\
\hline \multirow{4}{*}{ imine form } & $371(0.022)$ & $371(0.028)$ & $370(0.028)$ & $370(0.027)$ & $367(0.034)$ \\
\hline & $362(0.089)$ & $362(0.083)$ & $362(0.083)$ & $282(0.071)$ & $361(0.079)$ \\
\hline & $285(0.094)$ & $283(0.089)$ & $281(0.089)$ & $280(0.023)$ & $279(0.093)$ \\
\hline & $270(0.221)$ & $268(0.185)$ & $267(0.189)$ & $268(0.186)$ & $267(0.190)$ \\
\hline \multirow{3}{*}{ keto form } & $385(0.277)$ & $383(0.220)$ & $386(0.280)$ & $377(0.252)$ & $382(0.25)$ \\
\hline & $317(0.260)$ & $375(0.037)$ & $315(0.285)$ & $355(0.021)$ & $315(0.29)$ \\
\hline & $274(0.621)$ & $315(0.303)$ & $275(0.399)$ & $312(0.346)$ & $272(0.58)$ \\
\hline
\end{tabular}

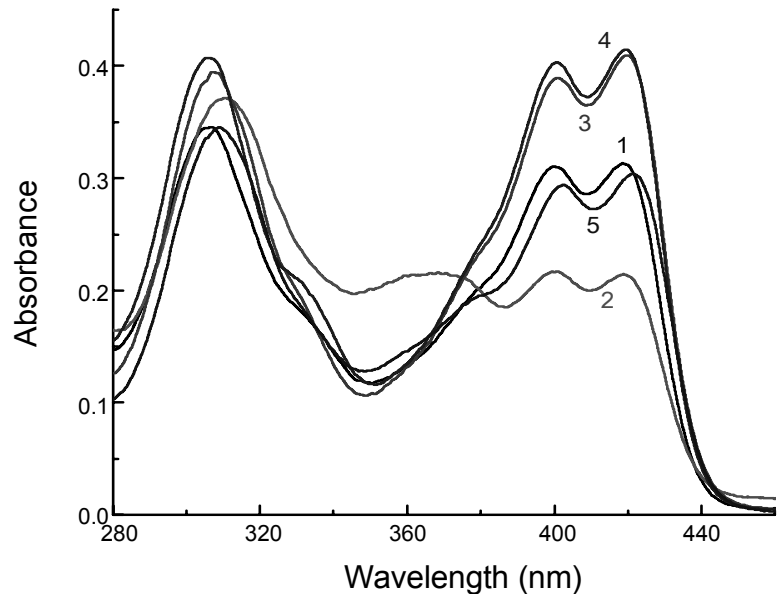

Figure 2. Electronic absorption spectra of $2.0 \times 10^{-4} \mathrm{M}$ solution of the compounds 1-5 in ethanol. compounds 1-5 were determined from their spectral behavior in buffer solutions of varying $\mathrm{pH}$ 's. For this purpose a universal buffer solutions ( $\mathrm{pH} 3.0$ - 12.5) containing 20\% (w/w) ethanol to complete ensure solubility of the Schiff bases was used. Representative spectra is shown in Figure 5. Values of $\mathrm{p} K_{\mathrm{a}}$ were determined by making use of three different Spectrophotometric methods, namely the half curve-height, the limiting absorbance and the isosbestic point methods. ${ }^{56,57}$ The obtained values are reported in Table 6 . Generally, it has been found that by increasing the $\mathrm{pH}$ value of the medium, the intramolecular $\mathrm{CT}$ band exhibits a high red shift in its $\lambda_{\max }$. This is due to the ionization of the aldehyde $\mathrm{OH}$ group (Figure 5). This red shift can be explained on the basis that, the ionization process facilitate the CT transitionlow energy is required for such transition. Beyond any reasonable doubt the obtained isosbestic point revealing the establishment of equilibrium between the neutral and ionic forms of these compounds. If HA represents the molecule of the Schiff 

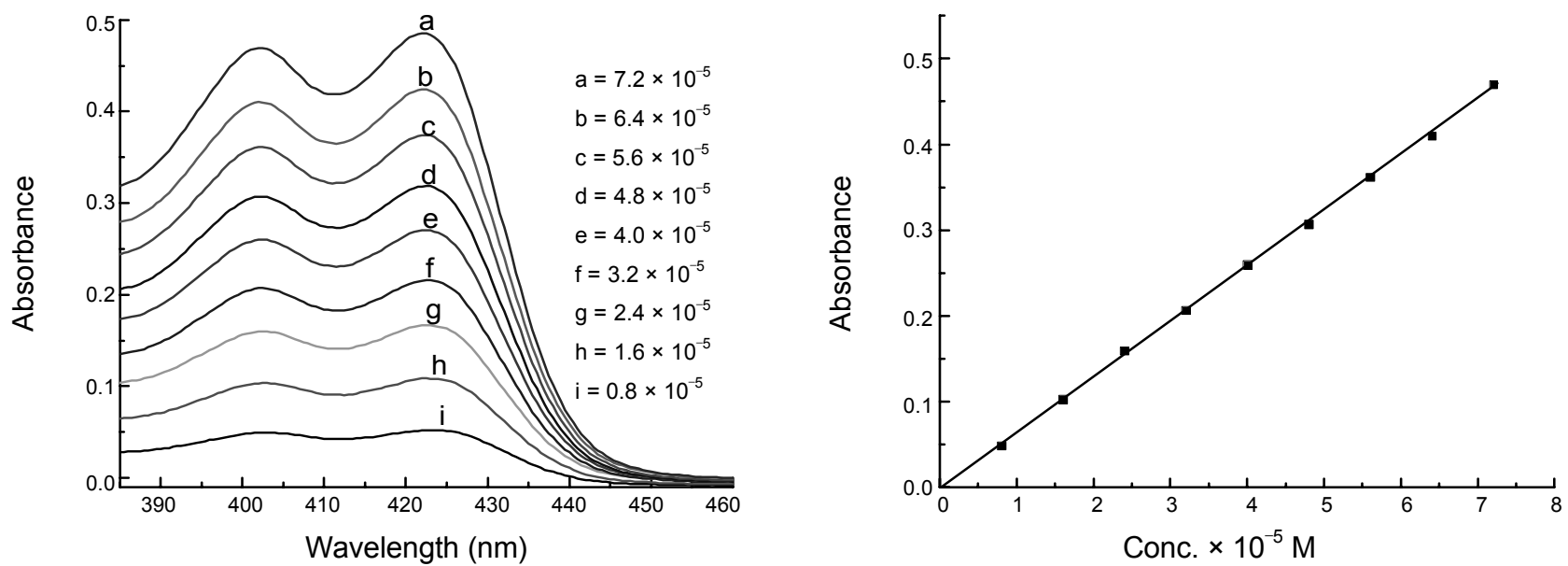

Figure 3. Effect of concentration of compound 4 in DMF.

(A)

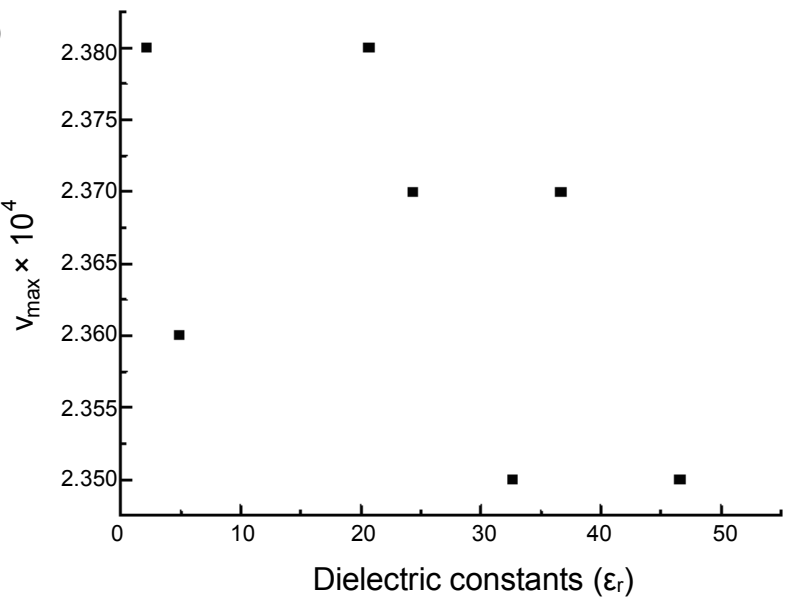

(B)

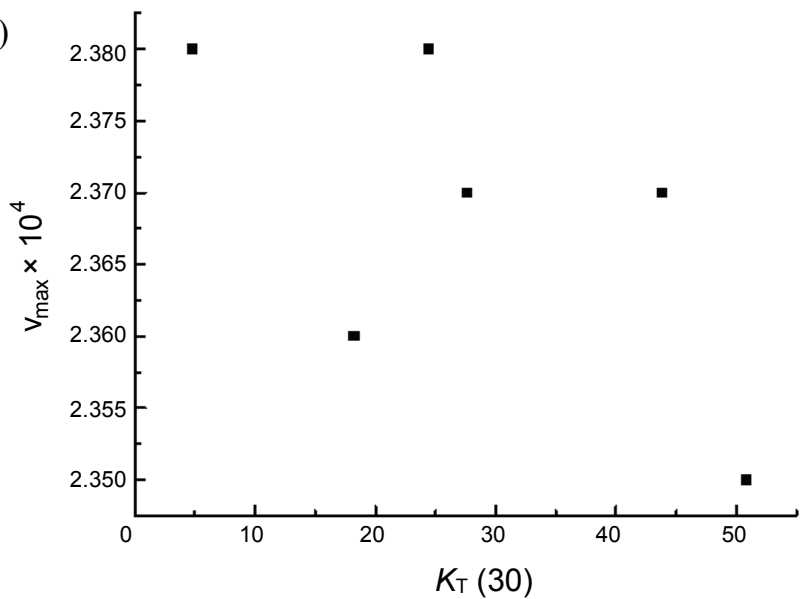

Figure 4. Plots of $v_{\max }$ for Schiff base 5 vs A-Dielectric constants $\left(\varepsilon_{\mathrm{r}}\right)$ and $\mathbf{B}$-Dimorth and Reichard solvent polarity parameter, $E_{\mathrm{T}}(30)$.

Table 5. Solvent parameters and $v_{\max } \times 10^{4} \mathrm{~cm}^{-1}$ of the compounds investigated

\begin{tabular}{|c|c|c|c|c|c|c|c|c|}
\hline \multirow{2}{*}{ Medium } & \multicolumn{3}{|c|}{ Solvent parameters } & \multirow{2}{*}{1} & \multirow{2}{*}{2} & \multirow{2}{*}{3} & \multirow{2}{*}{4} & \multirow{2}{*}{5} \\
\hline & $\varepsilon_{\mathrm{r}}$ & $K_{\mathrm{T}}(30)$ & $\pi^{*^{a}}$ & & & & & \\
\hline $\mathrm{C}_{2} \mathrm{H}_{5} \mathrm{OH}$ & 24.3 & 51.9 & 0.54 & 2.39 & 2.39 & 2.38 & 2.38 & 2.37 \\
\hline $\mathrm{CH}_{3} \mathrm{OH}$ & 32.6 & 55.4 & 0.60 & 2.39 & 2.38 & 2.36 & 2.37 & 2.35 \\
\hline DMF & 36.7 & 43.8 & 0.88 & 2.38 & 2.39 & 2.38 & 2.38 & 2.37 \\
\hline DMSO & 46.6 & - & 1.00 & 2.38 & 2.37 & 2.36 & 2.37 & 2.35 \\
\hline Acetone & 20.7 & 42.2 & 0.71 & 2.39 & 2.39 & 2.38 & 2.39 & 2.38 \\
\hline $\mathrm{CHCl}_{3}$ & 4.9 & 39.1 & 0.58 & 2.38 & 2.38 & 2.38 & 2.38 & 2.36 \\
\hline $\mathrm{CCl}_{4}$ & 2.2 & 32.4 & 0.28 & 2.39 & 2.39 & 2.38 & 2.39 & 2.38 \\
\hline
\end{tabular}

$\varepsilon_{\mathrm{r}}$-dielectric constants, $K_{\mathrm{T}}(30)$ - Dimorth and Reichardt solvent polarity parameter, $a$-is the general dipolarity of the solvent.

base compound, the following equilibrium is found in the universal buffer series (Scheme 2).

$$
\mathrm{HA} \rightleftharpoons \mathrm{A}^{-}+\mathrm{H}^{+}
$$

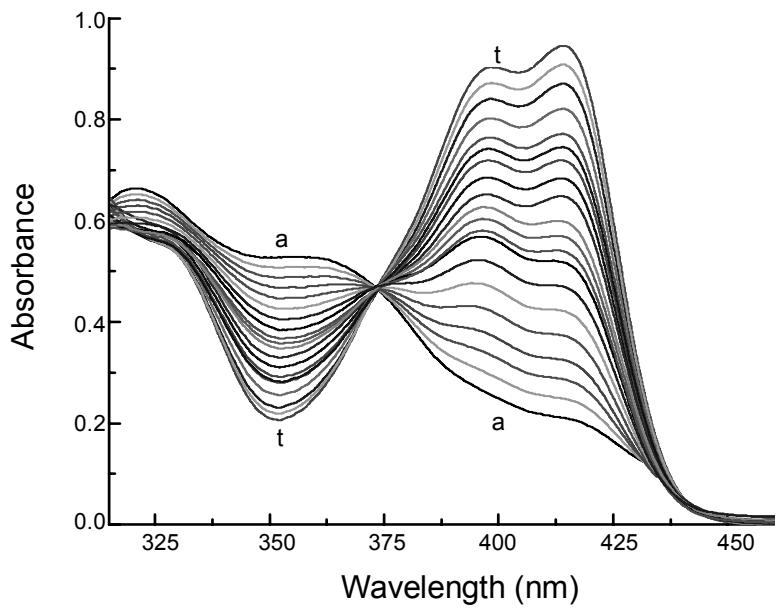

Figure 5. Electronic absorption spectra of $2.0 \times 10^{-4} \mathrm{M}$ solution of compound $3\left(\mathrm{R}=\mathrm{CH}_{2} \mathrm{CH}\left(\mathrm{CH}_{3}\right)_{2}\right)$ in universal buffer solutions containing $16.5 \%(\mathrm{w} / \mathrm{w})$ ethanol. $\mathrm{pH}^{*}$ (a) 3.75, (b) 4.01, (c) 4.28, (d) 4.54, (e) 4.81, (f) 5.08, (g) 5.34 , (h) 5.61 , (i) 5.87 , (j) 6.14 , (k) 6.41 , (l) 6.67 , (m) 6.94 , (n) 7.20, (o) 7.47, (p) 7.74, (q) 8.00, (r) 8.27, (s) 8.53, (t) 8.80. 
Table 6. Values of acidity constants $\left(\mathrm{p} K_{\mathrm{a}}\right)$ of the investigated compounds

\begin{tabular}{ccccc}
\hline \multirow{2}{*}{ Compound } & \multicolumn{4}{c}{$\mathrm{p} K_{\mathrm{a}}$} \\
\cline { 2 - 5 } & method 1 & method 2 & method 3 & mean \\
\hline $\mathbf{1}$ & 6.10 & 6.10 & 6.16 & 6.12 \\
$\mathbf{2}$ & 7.85 & 7.87 & 7.85 & 7.86 \\
$\mathbf{3}$ & 5.28 & 5.30 & 5.30 & 5.29 \\
$\mathbf{4}$ & 5.10 & 5.11 & 5.09 & 5.10 \\
$\mathbf{5}$ & 5.30 & 5.25 & 5.25 & 5.27 \\
\hline
\end{tabular}

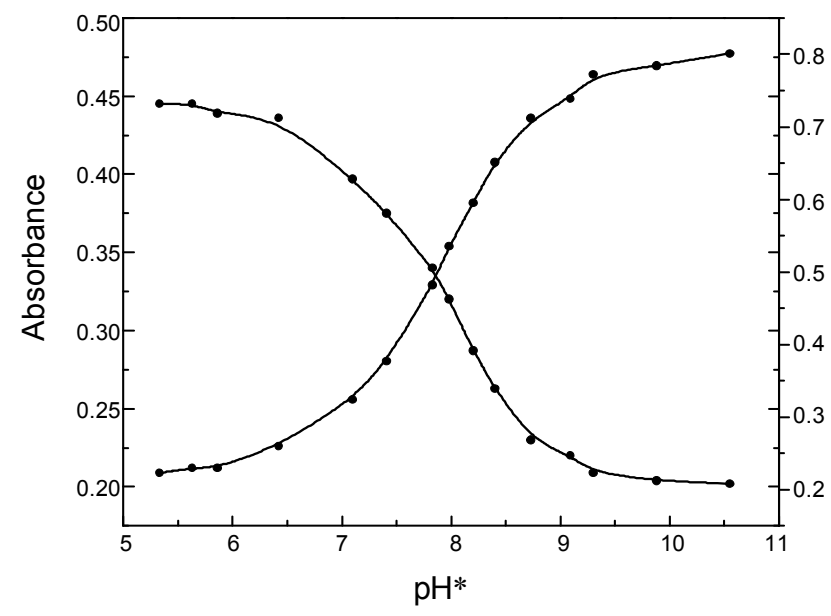

Figure 6. Absorbance-pH* curve of $2.0 \times 10^{-4} \mathrm{M}$ of compound 2 in universal buffer solutions containing $16.50(\mathrm{w} / \mathrm{w})$ ethanol.

The constructed absorbance-pH* relations at the selected wavelength are sigmoidal curves shaped, each comprising a clear inflection, indicating typical dissociation processes (Figure 6). In the light of the determined ionization constant values, the acidity constants $\left(\mathrm{p} K_{\mathrm{a}}\right)$ increases according to the following sequence:

$$
\mathbf{4}<\mathbf{5}<\mathbf{3}<\mathbf{1}<\mathbf{2}
$$

The decrease in the $\left(\mathrm{p} K_{\mathrm{a}}\right)$ value is generally in agreement with the increase in the electron releasing ability of the constituent $\mathrm{R}$ of the amino acids.

\section{Conclusion}

Electronic absorption spectra, being complementary to ${ }^{1} \mathrm{H}$ NMR investigations and theoretical calculations, provided new information on the keto-imine tautomerism of amino acid Schiff bases in different organic solvents. Infrared spectra of the studied compounds showed bands which suggest the presence of considerable quantities of both forms. DFT method revealed that keto forms are almost non-planar and imine forms are less thermodynamically stable than the former ones. Calculations at the COSMO level demonstrate that the inclusion of the medium provides enthalpies of formation in solution that are lower than those in the gaseous phase. Furthermore, keto and imine tautomers are thermodynamically preferred and can coexist in equili- brium as a consequence. The characteristic visible electronic bands appearing in the range $400-422 \mathrm{~nm}$ of the compounds under study were attributed to the $\mathrm{CT}$ transition within imine and keto forms.

Acknowledgments. The authors would like to thank A.M. Abdelmawgoud, professor of inorganic chemistry, Sohag University for his kind help.

\section{References}

1. Fedorov, B. S.; Volyanskii, Y. L.; Shevehuk, M. I. Khim.-Farm Zh. 1978, 12, 77 .

2. Bolotin, B. M.; Etingen, N. B.; Lastovskii, R. P.; Zeryukina, L. S.; Safina, R. U. Zh. Org. Khim. 1977, 13, 375.

3. Dikusar, E. A.; Kozlov, N. G. Russ. J. Org. Chem. 2006, 42, 369.

4. Mishra, V.; Pandeya, S. N.; Anathan, S. Acta Pharm. Turc. 2000, $42,139$.

5. Tian, Y. P.; Duan, C. Y.; Zhao, C. Y.; You, X. Z.; Mak, T. C. W.; Zhang, Z. Inorg. Chem. 1997, 36, 1247.

6. Shetye, S. S.; Mayadeo, M. S.; Hexameshwar, N. B. Asian J. Chem. 1999, 11, 1379.

7. Miao, R.; Shuoling, L.; Rudong, Y.; Lau, Y.; Wenbing, Y. Indian J. Chem. Sec. A 2003, 42, 318.

8. Şakiyan, İ.; Yilmaz, H. Synth. React. Inorg. Met.-org. Chem. 2003, 33, 971 and references therein.

9. Şakiyan, İ. Trans. Met. Chem. 2007, 32, 131.

10. Shebl, M. Spectrochim. Acta A 2009, 73, 313.

11. Montazerozohori, M.; Joohari, S.; Musavi, A. S. Spectrochim. Acta A 2009, 73, 231.

12. Omar, M. M.; Mohamed, G. G.; Ibrahim, A. A. Spectrochim. Acta A 2009, 73, 358.

13. Wang, M.; Wang, L. F.; Li, Y. Z.; Li, Q. X.; Xu, Z. D.; Qu, D. Q. Trans. Met. Chem. 2001, 26, 307.

14. Chatterjee, D.; Mitra, A.; Roy, B. C. J. Mol. Cat. 2000, 161, 17.

15. Tarasconi, P.; Capacchi, S.; Pelosi, G.; Corina, M.; Albertini, R.; Bonati, A.; Dall'Aglio, P. P.; Lunghi, P.; Pinelli, S. Bioorg. Med. Chem. 2000, 8, 154.

16. Mahmoud, M. R.; El-Gyar, S. A.; Moustafa, A. A.; Shaker, A. Polyhedron 1987, 6(5), 1017.

17. Palys, B. J.; Bukowska, J.; Jackowska, K. J. Electroanal. Chem. 1997, 428, 19.

18. Aly, A. A.; El-Shaieb, K. M. Tetrahedron 2004, 60, 3797.

19. Hadjoudis, E. In Photochromism: Molecules and Systems; Durr, H., Laurent, H. B., Eds., Elsevier: Amsterdam, 1990; pp 685.

20. Leuchtenberger, W.; Huthmacher, K.; Drauz, K. Appl. Microbiol. \& Biotechnol. 2005, 69(1), 1.

21. Şakiyan, İ; Gündüz, N.; Gündüz, T. Synth. React. Inorg. Met.-Org. Chem. 2001, 31(7), 1175.

22. Heinert, D.; Martell, A. E. J. Am. Chem. Soc. 1963, 85, 183.

23. Heinert, D.; Martell, A. E. J. Am. Chem. Soc. 1963, 85, 188.

24. Twine, S. M.; Murphy, L.; Phillips, R. S.; Callis, P.; Cash, M. T.; Szabo, A. G. J. Phys. Chem. B 2003, 107, 637.

25. Ebead, Y. H.; Roshal, A. D.; Wróblewska, A.; Doroshenko, A. O.; Blazejowski J. Spectrochim. Acta A 2007, 66, 1016.

26. Ebead, Y. H.; Fandy, R. F.; Zayed, S. E.; Abd-Elshafi, E.; Ibrahim, S. A. Can. J. Anal. Sci. Spectrosc. 2009, 53(6), 274.

27. Salman, H. M. A. Can. J. Anal. Sci. Spectrosc. 2000, 45(5\&6), 117.

28. Dal, H.; Süzen, Y.; Şahin, E. Spectrochim. Acta A 2007, 67, 808.

29. Britton, H. T. S. Hydrogen ions; Chapman Hall: London, 1952; pp 364.

30. Douheret, G. Bull. Soc. Chem. Fr. 1967, 4, 1412.

31. Douheret, G. Bull. Soc. Chem. Fr. 1968, 8, 3122.

32. Stewart, J. J. P. J. Mol. Model. 2007, 13, 1173.

33. Labanowski, J. K., Andzelm, J. W., Eds.; Density Functional Met- 
hods in Chemistry; Springer Verlag: New York, 1991.

34. Baker, J. J. Comput. Chem. 1986, 7, 385.

35. Schlegel, H. B., Ed.; Modern Electronic Structure Theory: Geometry Optimization on Potential Energy Surfaces; World Scientific: Singapore, 1994.

36. Francl, M. M.; Pietro, W. J.; Hehre, W. J.; Binkle, J. S.; Gordon, M. S.; Defrees, D. J.; Pople, J. A. J. Chem. Phys. 1972, 77, 3645.

37. Hariharan, P. C.; Pople, J. A. Theor. Chim. Acta 1973, 28, 213.

38. Becke, A. D. Phys. Rev. A 1988, 38, 3098.

39. Becke, A. D. J. Chem. Phys. 1993, 98, 1372.

40. Lee, C.; Yang, W.; Parr, R. G. Phys. Rev. B 1988, 37, 785.

41. Handy, N. C.; Tozer, D. J.; Laming, G. J.; Murray, C. W.; Amos, R. D. Isr. J. Chem. 1993, 33, 331.

42. Frisch, M. J.; Trucks, G. W.; Schlegel, H. B.; Scuseria, G. E.; Robb, M. A.; Cheeseman, J. R.; Montgomery, J. A.; Vreven, T. Jr.; Kudin, K. N.; Burant, J. C.; Millam, J. M.; Iyengar, S. S.; Tomasi, J.; Barone, V.; Mennucci, B.; Cossi, M.; Scalmani, G.; Rega, N.; Petersson, G. A.; Nakatsuji, H.; Hada, M.; Ehara, M.; Toyota, K.; Fukuda, R.; Hasegawa, J.; Ishida, M.; Nakajima, T.; Honda, Y.; Kitao, O.; Nakai, H.; Klene, M.; Li, X.; Knox, J. E.; Hratchian, H. P.; Cross, J. B.; Bakken, V.; Adamo, C.; Jaramillo, J.; Gomperts, R.; Stratmann, R. E.; Yazyev, O.; Austin, A. J.; Cammi, R.; Pomelli, C.; Ochterski, J. W.; Ayala, P. Y.; Morokuma, K.; Voth, G. A.; Salvador, P.; Dannenberg, J. J.; Zakrzewski, V. G.; Dapprich, S.; Daniels, A. D.; Strain, M. C.; Farkas, O.; Malick, D. K.; Rabuck, A. D.; Raghavachari, K.; Foresman, J. B.; Ortiz, J. V.; Cui, Q.; Baboul, A. G.; Clifford, S.; Cioslowski, J.; Stefanov, B. B.; Liu, G.; Liashenko, A.; Piskorz, P.; Komaromi, I.; Martin, R. L.; Fox, D. J.; Keith, T.; AlLaham, M. A.; Peng, C. Y.; Nanayakkara, A.; Challacombe, M.;
Gill, P. M. W.; Johnson, B.; Chen, W.; Wong, M. W.; Gonzalez, C.; Pople, J. A. Gaussian 03, Revision D.01: Gaussian, Inc.: Wallingford CT, 2004.

43. MOPAC2009, Stewart, J. J. P. Stewart Computational Chemistry, Version 9.025W web: http://OpenMOPAC.net.

44. Dewar, M. J. S.; Zoebisch, E. G.; Healey, F. F.; Stewart, J. J. P. J. Am. Chem. Soc. 1985, 107, 3902.

45. Nakamoto, K. Application in Coordination Chemistry. Infrared and Raman Spectra of Inorganic and Coordination Compounds, 5th ed.; John Wiley\&Sons, Inc.: 1997; New York, p 66.

46. Özcan, Y.; İde, S.; Şakıyan, İ.; Logoglu, E. J. Mol. Struct. 2003, 658, 207.

47. Breneman, C. M.; Wiberg, K. B. J. Comput. Chem. 1990, 11, 361.

48. Hgelin, D.; Sixl, H. Chem. Phys. 1983, 77, 391.

49. Cohen, M. D.; Schmidt, G. M. J.; Flavian, S. J. Chem. Soc. 1964, 2041.

50. Issa, R. M.; Khedr, A. M.; Rizk, H. F. Spectrochim. Acta A 2005 , 62,621 .

51. Briegleb, G. Electron Donor-Acceptor Complex; Springer Verlag: Berlin, 1961.

52. Buncel, E.; Rajagopal, S. J. Org.Chem. 1989, 54, 798.

53. Reichardt, C. Solvents and Solvent Effects in Organic Chemistry, 2nd ed.; VCH: Weinheim, 1990; p 432.

54. Hutching, M. G. Dyes Pigments 1991, 17, 227.

55. Liu, Q.; Fang, D.; Zheng, J. Spectrochim. Acta A 2004, 60, 1453.

56. Issa, R. M.; Sadek, H.; Izzat, I. I. Z. Phys.Chem. 1971, 74, 17.

57. Issa, R. M.; Hammam, A. S.; Etaiw, S. H. Z. Phys. Chem. 1972, 251,177 